DOI: 10.29295/2311-7257-2019-96-2-66-71

УДК 72.01

\author{
Qasim M. B., Semka S. V. \\ Kiev National University of Construction and Architecture \\ (Vozduhoflotsky avenue, 31,03680,Kiev,Ukraine; e-mail: qasim.m.qaisi@gmail.com; \\ orcid.org/0000-0003-2699-832)
}

\title{
THE INTEGRATION OF FORM, IMAGE AND CHARACTER WITH THE FUNCTION IN AIRPORT TERMINAL DESIGN
}

The aims of this research are to try and examine how to integrate form, image and character with function in airport design and hence giving the passengers a meaningful experience through the airport terminal. In the late 20th and the 21 st century, the design of the airport began to transform from just the design for function but it started to look and incorporate aesthetic issues in design. This article will look at the transformation of airport design in relation to exterior or form and image and how airport character acts as visual representation and how it affects the user of the space. The article is attempting to resolve lack of meaning in modern airport design.

Keyword: airport architecture, terminal design, form, modern airport, functional planning.

Introduction. The airport is one of the most uniquely designed buildings of the 20th century. The earlier airplanes took off from open grass fields and the airport consisted of a hangar for storage and servicing of the plane and an observation stand for visitors. Today the airport has evolved into a new generation state of the art hybrid building with multifunctional operations. The airport is the gateway to many countries and so the design of the terminal aesthetically as viewed from the air and the ground is such a crucial to any country. Since the design of the first airport a lot of transformation and evolution has taken place in the form, image, character, Spatial design, materials used in airport terminals. Airports are a key transportation modal point and their design should stand through time to be appreciated by past, current and future generations. The airport terminal is the central building of the airport system. Its architecture reflects the glamour, scale and technological prowess of this fast-growing industry. As air travel became more popular and accessible, the airport has assumed greater importance as a fundamentally new and challenging building. It is a miniature city reflecting the values and aspiration of the society. National image is reflected more directly in the design of airports than in any other building type, with the passenger terminal the key element in public perception. Airport authorities have been for half a century, one of the most adventurous patrons of modern architecture. From Eero Saarinen TWA terminal of 1959 at the JFK airport to Renzo piano's
Kansai airport of 1995, airport developers have been consistent in their support of innovative design whether expressed in formal or technological terms.

The problem of the research. Building should have a specific language in their form; one should be able to clearly tell the difference between institutional buildings from a transport terminal building or even from an office block. Airports as countries gateway should conform to some kind of design principle were the design should stay timeless in character, form and spirit. The main problems inherent to airport terminals are posed by their large size and scale and their complexity in function. The design of the airport gave function and efficiency the first priority, form image character and passenger needs took the second place. As Charles A. Lindbergh said, life it serves. In a small way, airports should try to solve the issue of critical regionalism where the design should borrow from the vernacular, picking up elements from it and developing it to a new level, like the TWA flight center in the JFK international airport in Queens New York borrowed its airport design from the eagle which is the countries symbol. The consequence of not achieving regionalism in design of airports leads to the lacking of a language and meaning in airport design. The aims of this research is to try and examine how best to integrate form image and character with function in airport design and hence giving the passengers a meaningful experience through the airport terminal [5]. 
Research objectives Analyze how through history the image and form of the terminal building is transforming and what is causing some of these transformations. Establish best practices in the terminal design in terms of the form. Identify variable that affects the form image and character of airport building. Research Questions: What variables are affecting airport buildings in relation to form image and character in reference to its built form? How has an airport design transformed since the first airport to the most recent? How does the form in airport design affect the different functions in the airport? What factors have led to the transformation of the image, form and character of the terminal building.

History of airport design. According to Edwards (1998) he says that the introduction of wide-bodied aircrafts such as the Boeing 747 in the 1970 resulted in the not only lengthening of the runway but also in the enlargement of the terminal building and the access piers to accommodate the influx of passengers arriving in great waves. It is feasibly today to design and build aircrafts capable of carry 1000 passengers, but with double Decker planes, they would need double Decker piers and greater terminals. Aircrafts in the 1990s has concentrated upon new safety levels, greater comfort, less noise and more fuel-efficient planes. Such aircrafts have stabilized at seating levels of about 450500 (as in the Boeing 777) but with the new design from the airbus of the A380 carrying more than 850 passengers, it has led to the revolution of the air industry. If by chance a terminal receives, three such planes with full capacity the terminal would come to a standstill and so the design needs to be improved for such occasions. Hugh Pear man (2004), says that architects of today's airport buildings are celebrated, from Eero Saarinen to Renzo Piano, Richard Rogers and Norman Foster to Ricardo Bofill, but it is rarer to regard a designer such as Joseph F. Sutter, creator of the Boeing 747.according to Norman foster he thinks of him as an architect. in 1991 foster said; "with about three thousand square feet of floor space, fifteen lavatories, three kitchens and a capacity for up to three hundred and seventy guests, this is surely a true building. The fact that we call this an aero plane rather than a building-or engineering rather than architecture-is really a historical hangover because for me, much of what we have here is genuinely architecture both in design and in its thinking [6].

Passenger volumes and planning of spaces. Pearman (2004) states that there are factors which influence the extent of passenger amenities and terminal building design. Some of this includes the passenger volume, community size, the location and extent offairport services, interests and abilities of potential concessionaires, and rental rates. The passenger volume affects the design and the size of the spaces in the terminal building. The following are spaces that are greatly affected by the passenger volume in the airport building at any particular point. The spaces are calculated according to the FAA regulations of airport design in reference to the passenger volume. These are the spaces greatly affected by passenger volume. (1. Ticketing/check-in 2. Passenger screening 3. Hold rooms 4. Concessions 5. Baggage claim 6. Circulation 7. Airline offices and operations areas 8. Baggage handling 9. Baggage screening system 10. International facilities).

Function and planning. Passenger volume has affected different functions in an airport and can affect the external form of the building in its character and image. There are different locations in an airport terminal that have specific function and so the design would conform to certain characteristics, this is all according to Horonjeff et al (1993). They debate about form follows function is not considered in the airport industry design since the trend these days is designing iconic terminals then the function follow. But in some cases, the function may dictate the design of a terminal like for example the blast area at the main entrance of any terminal affects form since they would receive double reinforcement and the materials used there should be of high strength to reduce the impact in case of a terrorist attack. "Form Follows function" was coined by American architect Louis Sullivan, and as a result Frank Lloyd Wright, who was Sullivan's assistant in the office, adopted the phrase "form follows function". The Guggenheim Museum is 
a good example of Wright's application of the principle. The design with a spiral shape was intended to allow visitors to easily view the artwork within. The following are a couple of airport design that has changed due to different passenger volumes through the years. There are several basic approaches to the design of terminal buildings in airports, and how they are evolving with time according to Horonjeff et al (1993) [1].

Transformation of form. Nikolaus (1996) says that as a result of new aero plane design the airport building is greatly affected in its design and nowadays airport architect has conformed and hence there has being a revolution and transformation of form in airport buildings. Transformation in any building is described and broken down in various ways. According to form space and order Ching (1996) he says, Transformation can be understood as a manipulation of the primary solids. Transformation of form is created by variations, which are generated by the manipulation of one or more dimensions or by additional, or subtraction of elements. There are a couple of types of transformation of form and they include; Dimensional transformation According to Ching (1996) This is when a form can be transformed by altering one or more of its dimensions and retain its identity as a member of a family of form for example a cube can be transformed into similar prismatic forms through discrete changes in width ,height or length. Subtractive transformation On the extent of the subtractive process the form can retain its initial identity for example a cube can retain its identity even though a portion of it is removed. Additive transformation A form can be transformed by the addition of elements to its volume. The nature of the additive process and the number and relative sizes of the elements being attached determine whether the identity of the initial form is altered or retained [8].

Aircraft types and passenger terminal design. According to Edwards (1998) he states that there are four main scale of air transport and they are intercontinental, continental, regional and commuter and are each served by their own type and category of aircraft. Transport by the first is in such aircraft as the Boeing 747 (with seating capacity for
400), the second by say the European Airbus A310 (seating 250), the third by the Boeing 737 (Seating $150-200$ ) and the fourth by the SAAB 340 (seating 35). Each scale of jet has its own apron, servicing and terminal design needs though there are overlaps between the four main categories of aircraft, and the designer of the airports knows that if each scale is accommodated, then those planes between the capacity bands will fit comfortably into the system. as a general rule, journeys over $3000 \mathrm{~km}$ are seen as intercontinental, between 3000 and $1500 \mathrm{~km}$ as continental, under $1500 \mathrm{~km}$ as regional and under $300 \mathrm{~km}$ as commuting. While the intercontinental and continental market is met by jet aircraft, the lower end of the regional scale and commuter market is increasingly served by turboprops (a type of turbine engine which drives an aircraft propeller using a reduction gear). The new generation of turboprops offers distinct advantages over jet aircraft: they are less noisy, can operate at lower altitudes; have reduced emissions and shorter take-off and landing space needed. Edwards (1998) says that the growth in commuter journeying by plane is being meant not by small noisy jets but by relative quiet and fuel-efficient turboprops such as the SAA 2000 .in fact while larger jet aircrafts are increasingly constrained by environmental regulations of one kind or another, the new generation of turbo props with their improved performance readily meet international standards. According to him, the terminal building has to be capable of accommodating all four scales of commercial aircraft listed earlier. The most problematic area is normally concerning commuter aircrafts, where smallness of size, the need to take off and land quickly, and unusual aircraft design features put terminal, gate lounge, runways and apron facilities under greatest strain. Edwards (1998) says "However, looking further to the future (10-20 years), a new generation of aircraft now undergoing technical investigation may require wider modifications to airport design." Edwards (1998) argues that two trends are emerging that, if realized will alter the assumption under which the airline and airport industries operate. The first concerns the reemergence of supersonic passenger 
aircraft. Design and technological research is being devoted to a new generation of supersonic aircraft based upon the experience of Concorde. Several manufacturers are collaborating to develop a quieter, faster, more fuel efficient and large capacity planes. With business travel growth still buoyant, and the world's biggest trading nations at opposite geographical regions, aircrafts designers realized that very high-speed travel has commercial advantages. The age of mass supersonic commercial air transport will probably occur well within the life time of airport currently being designed (being 50 years). The second innovation concerns very large aircrafts, perhaps capable of carrying 1000 or more passengers. The airbus industries, Boeing and McDonnell Douglas are developing prototypes designs in this field. Because of this the passenger terminal the implications for the organization and distribution of space, catering, ticketing and baggage handling will be profound. To meet such demands design of the terminal building has to be robust in concept and capable of multiple adaptations over time. According to Edwards (1998) the life of an airport terminal, is about $50 \mathrm{yrs}$., is two or three times as long as the aircraft it serves, and frequently longer than the life of an airline company. In an industry of little stability, the airport is the one permanent feature. Even the airport, though, does not stand still; it replaces obsolete ground transport system, and regularly upgrades air traffic control facilities. At the Heathrow there are now five terminals, while terminal 1 has been substantially rehabilitated and extended at least twice in its 30 years of life. These changes are driven by two main factors: the increase in passenger volume, and the evolving of aircraft design. Innovation in aircraft design triggers a chain reaction throughout the industry, which airline management, airport operation and passenger terminal design have them to meet. Due to very high passenger volume increase and changes in aircraft design this must be resultant and it should affect the terminal design. The passenger terminal has to be capable of meeting change, but the architect is rarely able to anticipate what specific shape or direction that change will take. Flexibility expandability and functional adaptability are the obvious design philosophies to adopt within the constraints of structural robustness and aesthetic appeal.

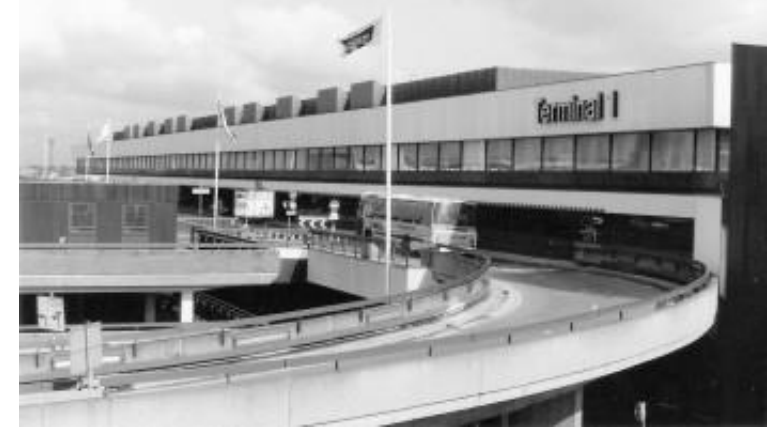

Fig. 1 Heathrow Airport Terminal 1

Source: www.headforpoints.com

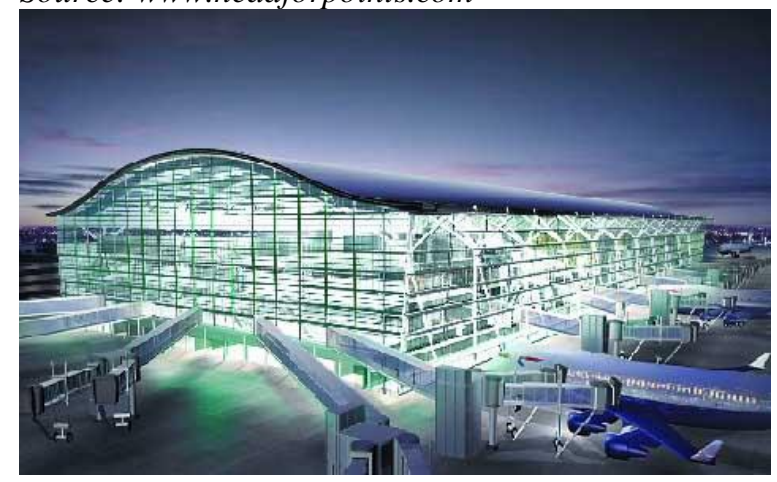

Fig. 2 Heathrow Airport Terminal 5

Source: www.e-architect.co.uk

Terminal building design and effect on form image and character. Edwards (2005) says that the trend these days is away from ownership of airports by the state (either central or regional government) towards either private ownership or partnership between the government and private investors. London Stansted is owned by BBA (which is wholly private and quoted in the stock exchange), and other major airports, such as the Stuttgart in Germany and Milan in Italy, have been denationalized and are now no longer state owned. He says the reasons are clear: airports require massive injection of funds to adapt to changing regulations, market conditions and commercial opportunity. Only with private capital can the outmoded infrastructure of airports be kept up to date. In the developing world according to Edward (2005) he says that it is still a commonplace for the state or local authority to own and manage airports, but as soon as they become profitable, they are quickly sold, often to international organization. although many government clings to the idea that their major 


\section{Cepia "APXITEKTYPA》}

airports are part of the state infrastructure of public utilities, in reality the past 10 years have seen a shift worldwide away from government towards some sort of consortium ownership or total private ownership. Edward (2005) says, "The pattern of ownership throughout the world tends to follow the varying ideologies of the respective government rather than any obvious regional or sub continental pattern". Ownership of airports by the government is declining, there remains a strong group of airports (such as the Kansai in Japan) run by a consortium of state and local government with private companies having financial stake. Sometimes the airport may be owned by the arm of the government, but the principal building (such as the passenger termini) are owned, leased or managed by a private organization such as airline companies. The mix of ownership has implications for the operation of the airport and- to some extent- for the design of the part. Where ownership is vested in government, they tend to be a controlling hand over the appearance of the whole airport estate, from hotels to car parks, terminal building to control towers. Edward (2005) says that where ownership is fragmented, or resides in a consortium, there is usually greater pluralism in the approach to design, and often the employment of a wider selection of architects, designers and engineers. Where there is a split in ownership between the airport and its key building (as the Kennedy Airport, New York) the pattern is usually one where different airline own specific terminals. Therefore, the terminal building has very different image in terms of form image and character because of different ownership. This allows them to compete with each other as integrated terminal-based service- including ticketing, baggage handling and concessionary shop-all managed by the airline company with which the passenger is flying [2].

Conclusions. The airport is the gateway to many countries and so the design of the terminal aesthetically as viewed from the air and the ground is such a crucial to any country. The airport terminal is the central building of the airport system. Its architecture reflects the glamour, scale and technological prowess of this fast-growing industry.
Airports as countries gateway should conform to some kind of design principle were the design should stay timeless in character, form and spirit. there are factors which influence the extent of passenger amenities and terminal building design. Some of this includes the passenger volume, community size, the location and extent off-airport services. The passenger volume affects the design and the size of the spaces in the terminal building. The spaces are calculated according to the FAA regulations of airport design in reference to the passenger volume. These are the spaces greatly affected by passenger volume. New aero plane designs the airport building is greatly affected in its design and nowadays airport architect has conformed and hence there has being a revolution and transformation of form in airport buildings. Flexibility expandability and functional adaptability are the obvious design philosophies to adopt within the constraints of structural robustness and aesthetic appeal. the terminal building has very different image in terms of form image and character because of different ownership.

\section{REFERENCES:}

1. Horonjeff R., Mc Kelvey F. X. Planning and design of airports, 4th edition, New York: McGraw-Hill Inc. 1993. 848 p.

2. Edwards B. The modern airport terminal, 2nd edition, Taylor and Francis publisher, 2005. 304 p.

3. Gage M. F. Aesthetic theory. Essential texts for architecture and design. W. W. Norton \& Company, 2011.336 p.

4. Winters E. Aesthetics and architecture. Continuum international publishing group, 2007. $192 \mathrm{p}$.

5. Norton Ch. E. Principles of Architectural composition. Published university press of New England, 1946.

6. Pearman H. Airports, a century of architecture, published Harry N. Abrams, 2004. 240 p.

7. Van Uffelen C. Airport architecture. Braun Publishing, 2012. 272 p.

8. Ching F. D.K. Architecture Form, Space, and Order. Published by John Wiley \& Sons, 2015. $466 \mathrm{p}$.

9. Pevsner N. A history of building types. Published Thames \& Hudson Ltd, 1979. 352 p.

10. Geofrey.H.B, Design Strategies in Architecture: An Approach to the Analysis of Form. Published Taylor \& Francis, 1996. 352 p. 
Касім М. Б., СемКа С.В. ІНТЕГРАЦІЯ ФОРМИ, ЗОБРАЖЕННЯ ТА ХАРАКТЕРУ 3 ФУНКЦІЕЮ В КОНСТРУКЦЇ̈ ТЕРМІНАЛУ АЕРОПОРТУ. Мета цієї статті - з'ясувати, як найкращим чином інтегрувати форму, зображення i характер з функцією в дизайні аеропорту i, отже, дати пасажирам значний досвід через термінал аеропорту. В кінці 20-го і 21-го століття дизайн аеропорту почав трансформуватися не тільки через функціональності, але і став враховувати естетичні аспекти дизайну. У цьому дослідженні буде розглянуто зміна дизайну аеропорту по відношенню до зовнішнього вигляду або формі і зображенню, а також те, як персонаж аеропорту виступає в якості візуального представлення і як це впливає на користувача простору і намагається вирішити відсутність сенсу в сучасному дизайні аеропорту.

Ключові слова: архітектура аеропорту, дизайн терміналу, форма, сучасний аеропорт, функціональне планування.
Касим М. Б., Семка С.В. ИНТЕГРАЦИЯ ФОРМЫ, ИЗОБРАЖЕНИЯ И ХАРАКТЕРА С ФУНКЦИЕЙ В КОНСТРУКЦИИ ТЕРМИНАЛА АЭРОПОРТА. Цель этой статьи - выяснить, как наилучшим образом интегрировать форму, изображение и характер с функцией в дизайне аэропорта и, следовательно, дать пассажирам значимый опыт через терминал аэропорта. В конце 20-го и 21-го века дизайн аэропорта начал трансформироваться не только из-за функциональности, но и стал учитывать эстетические аспекты дизайна. В этом исследовании будет рассмотрено изменение дизайна аэропорта по отношению к внешнему виду или форме и изображению, а также то, как персонаж аэропорта выступает в качестве визуального представления и как это влияет на пользователя пространства и пытается решить отсутствие смысла в современном дизайне аэропорта.

Ключевые слова: архитектура аэропорта, дизайн терминала, форма, современный аэропорт, функциональное планирование.

DOI: 10.29295/2311-7257-2019-96-2-71-76

УДК 628.979

\section{Кононенко Г.Ю}

Харківський національний університет міського господарства імені О.М. Бекетова (вул. Маршала Бажанова, 17, Харків, 61000, Україна; e-mail: anndis13@gmail.com; orcid/org 0000-0002-6102-0967)

\section{ПРИНЦИПИ ПОБУДОВИ СВІТЛОВОГО ОБРАЗУ АРХІТЕКТУРНОГО ОБ'ЄКТУ}

В даній роботі розглядаються питання побудови світлового образу об'єкту. що є результатом взаємодії світла та трьох категорій архітектурної форми (об’єму, пластики, кольору). Автором запропонована методологія

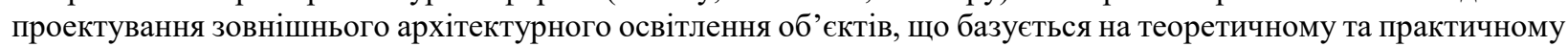
досвіді в цій сфері.

Ключові слова: світловий образ, світлооб'ємне проектування, світлокольорові характеристики, штучне освітлення, світлопланувальна структура

Одним з напрямів світлооб'ємного проектування є вирішення питань взаємодії світла та трьох категорій архітектурної форми (об’єму, пластики, кольору) [14]. Цей напрям є переважаючим в сучасній практиці проектування установок зовнішнього освітлення, він активно розглядається в науково-аналітичних роботах $[6,7,10,13,15]$.

При дослідженні особливостей освітлення окремого, «штучного» об'єкта, завжди необхідно враховувати його прив'язку до оточення (контексту). Важливим завданням стає забезпечення його візуального по'єднання 3 іншими елементами, оскільки перспективою є включення його в майбутній світловий ансамбль, або формування ансамблю на його основі.

Проектування зовнішнього архітектурного освітлення об'єктів відносять до жанру світлооб'ємного проектування [14]. Розроблена в роботі методологія передбачає послідовне вирішення низки завдань від загальних до конкретних. Зупинимося на них більш детально.

Завдання 1. Виявлення об'ємної форми об'єкта, іiї тривимірності, цілісності, монолітності або розчленованості, дрібності та, як окремий випадок, іiї двомірности. Здійснюється в основному за рахунок 